\title{
Teaching Material using SETS Approach for Volcanic Dust Disaster Mitigation
}

\author{
Cherly Salawane ${ }^{1,2, a)}$, Supriyadi ${ }^{3, b)}$, Ani Rusilowati ${ }^{3, c)}$, Dyah Rini Indriyanti ${ }^{3, d}$, \\ Achmad Binadja ${ }^{4, e)}$ \\ ${ }^{1}$ Natural Sciences Education Study Program, Postgraduate Universitas Negeri Semarang, Kelud \\ Utara III Street, Semarang 50237, Indonesia \\ ${ }^{2}$ Faculty of Teacher Training and Education, Universitas Halmahera, Wari Raya Street, Tobelo \\ 97762, Indonesia \\ ${ }^{3}$ Faculty of Mathematics and Natural Sciences, Universitas Negeri Semarang, Sekaran Gunungpati \\ Campus, Semarang 50229, Indonesia \\ ${ }^{4}$ Faculty of Health, Universitas Dian Nuswantoro, Imam Bonjol Street, Semarang 50131, Indonesia

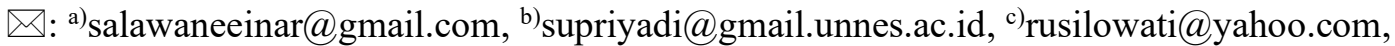 \\ d)dyahrini36@gmail.com, e)binadja2000@yahoo.com
}

\begin{abstract}
Mitigation education is a stage of preparedness to minimize losses due to a disaster. The purpose of this study is to develop teaching materials with the SETS (Science, Environment, Technology, and Society) approach Integrated Science subjects of solar system competencies and the earth surface structure to reduce the risk of the Mount Lokon volcanic ash disaster in North Sulawesi Province. This research uses Research and Development Methods. The subjects in this study were 30 students at SMP Kristen Credo Kolongan, Minahasa Regency. The results showed that the teaching material developed was declared valid by experts, practical was used, and effectively viewed from the cognitive aspect with an increase in the pretest score (54.5) to the posttest (92), and the affective aspects of the average score very good average (87.3) so that this teaching material is valid, practical, and effectively used in learning activities to reduce the risk of volcanic ash disaster.
\end{abstract}

Keywords: teaching materials, SETS, disaster mitigation

\section{INTRODUCTION}

Teaching materials developed can improve students' attitudes and attention towards learning activities because the material taught is easier to understand by students (Eren and Yagbasan 2017). Teaching material is a set of learning tools or tools containing learning materials to achieve the expected goals, namely achieving competence or sub competency with all complexity. The development of teaching materials or instructional materials is arranged into one reference that will support student development to balance physical and spiritual needs (Widodo and Jasmadi 2008). The development of teaching materials provides benefits for teachers and students. The benefits obtained by the teacher are teaching materials following the demands of the curriculum, do not depend on textbooks and government assistance package books (Nuvitalia, Novita, Suciati, and Cholifah 2020). Students' benefits are creating engaging learning, fostering motivation, reducing dependence, and getting ease in learning each indicator compiled by a teacher (Prastowo 2012). 
SETS are approaches that integrate science, environment, technology, and society in learning the subject matter. Learning science with an approach to science, environment, technology, and society can make students more interested because they will see the use of knowledge learned more broadly in real life (Maknun, Busono, and Surasetja 2018). After understanding the benefits of the knowledge learned, students will enjoy the lessons, and learning will bring students to be more familiar with science, environment, technology, and society (Supriyadi et al. 2019). Indirectly education with SETS directs students to have a concern and empathy for the environment and community systems. Science, environment, technology, and community-oriented learning must make students understand the relationship of each element. This inseparable relationship is a reciprocal relationship that can assess the benefits and losses incurred (Binadja 1999).

Education has an essential portion of disaster mitigation activities (Olu et al. 2018). Educational activities have a strategic impact, where it is expected that the community will obtain practical knowledge about disasters that is useful for dealing with disaster problems (Szente, 2016). On the other hand, this educational activity forms an attitude of self-responsiveness and awareness of the surrounding environment, a disaster-prone area (Rusilowati et al. 2012; Tseng, Chang, Lou, and Chen 2013). Education is a long-term defense against natural disasters that enables people to overcome the danger of disasters and directly influence risk perception and teach the skills and knowledge needed for disaster mitigation (Bernhardsdottir et al. 2016). To minimize the negative impact of disaster hazards, individual preparedness is required. Low personal preparedness in disaster-prone communities must be educated and encouraged to be ready for disasters (Kyne et al. 2020). Through the disaster education program, students are educated to become agents of change who can create disaster-resilient communities (Sakurai et al. 2020).

\section{METHODS}

The method used in this research is research and development methods. The design of teaching materials based on science, environment, technology, and society to mitigate volcanic ash disasters is based on the potential and problems in the field. Experts then validate teaching materials developed before being tested on limited subjects or limited classes on 15 students. The trials in limited classes are subject to the evaluation and improvement of product development results before being tested on a broad class with 30 students. The research stages of developing teaching materials can be seen in FIGURE 1. The research stages of developing teaching materials.

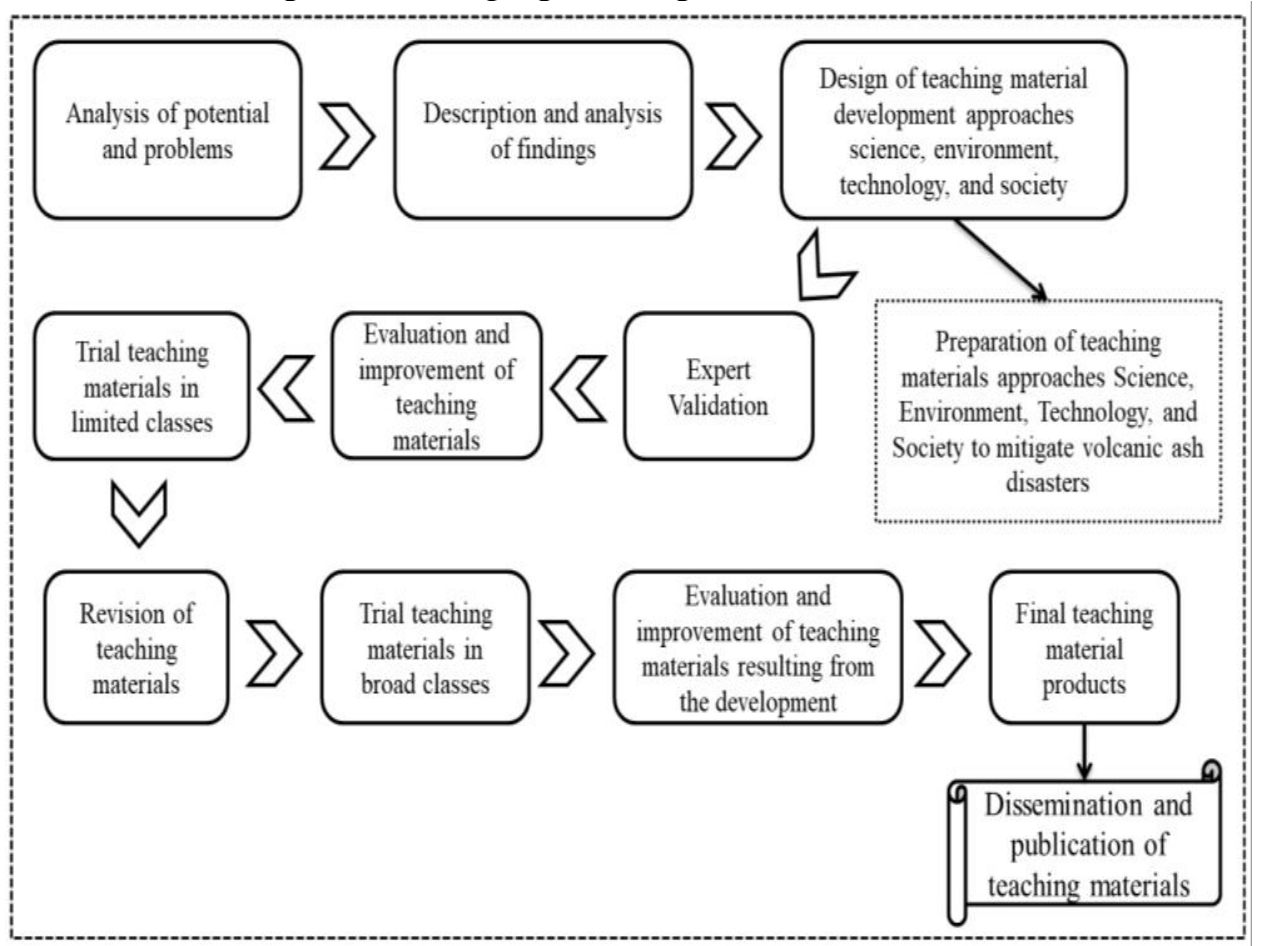

FIGURE. 1 The research stages of developing teaching materials (Salawane et al. 2019). 
This research was conducted at the SMP Kristen Credo Kolongan, Minahasa Regency, North Sulawesi Province. The subjects in this study were class IX students who supported 30 people. The study design used a pretest-posttest group design. Where 30 of these students use conventional teaching materials after getting compliments of mastery learning. Furthermore, 30 students in the same class use teaching materials from the development and sponsored learning completeness. To see student learning achievement of the minimum completeness criteria, learning outcomes using conventional teaching materials are compared with learning outcomes using teaching materials developed.

The data analysis used in this development research is a descriptive statistical analysis technique:

\section{Validity and Practicality of Teaching Materials}

Teaching materials that have been validated by experts are analyzed descriptively. Furthermore, the teaching materials were tried out in limited classes to test the practicality of the teaching materials that had been developed. Descriptive statistical analysis uses the equation below:

$$
P=\frac{\text { acquisition score }}{\text { ideal score }} \times 100 \%
$$

\section{The Effectiveness of Teaching Materials}

The effectiveness of teaching materials is seen from the improvement of student learning outcomes. This increase is calculated using the Gain Index from the pretest and posttest.

$$
\text { Gain Index }=\frac{\text { PosttestScore- } \text { PretestScore }}{\text { MaximumScore- PretestScore }}
$$

\section{RESULTS AND DISCUSSION}

Based on the results of the analysis in Table 1. Identification of syllabus and lesson plans, teaching materials, and evaluation instruments in the SMP Kristen Credo Kolongan. TABLE 1 shows that teaching materials found at school have not shown students' active role in every teaching and learning activity. So, the teaching materials are approached by science, environment, technology, and society in integrated science subjects of solar system competencies and the earth's surface structure for mitigation volcanic dust disasters need to be developed.

TABLE 1. Identification of syllabus and lesson plans, teaching materials, and evaluation instruments in the SMP

\begin{tabular}{|c|c|c|c|}
\hline No & Learning Packages & Analysis of Field Findings & Development Results \\
\hline 1 & Syllabus and Lesson Plan & $\begin{array}{l}\text { The syllabus and lesson plan have not } \\
\text { yet integrated science competencies, } \\
\text { teachers have not created a learning } \\
\text { climate that allows students to apply } \\
\text { their conceptual understanding, both } \\
\text { through activities and solving } \\
\text { problems related to problems. }\end{array}$ & $\begin{array}{l}\text { Integration of science competencies } \\
\text { related to science, environment, } \\
\text { technology, and society directly } \\
\text { related to real life. }\end{array}$ \\
\hline 2 & Teaching Material & $\begin{array}{l}\text { Teachers sometimes use textbooks, } \\
\text { learning is still centered on the } \\
\text { teacher (the teacher as a source of } \\
\text { information), so students are required } \\
\text { to build their own learning concepts } \\
\text { with real life. }\end{array}$ & $\begin{array}{l}\text { The implications of the concept of } \\
\text { learning in everyday life include } \\
\text { elements of science, environment, } \\
\text { technology, and society contained in } \\
\text { competencies and sub-competencies } \\
\text { in teaching materials. }\end{array}$ \\
\hline 3 & Instrument of evaluation & $\begin{array}{l}\text { Learning outcomes test results have } \\
\text { not trained students' cognitive } \\
\text { abilities in solving problems related to } \\
\text { daily life. }\end{array}$ & $\begin{array}{l}\text { Problem testing results in problem- } \\
\text { based learning which includes four } \\
\text { elements, namely science, } \\
\text { environment, technology, and } \\
\text { society. }\end{array}$ \\
\hline
\end{tabular}
Kristen Credo Kolongan. 
The results of the preliminary study or analysis of findings in the field are shown in Table 1 . Identification of syllabus and lesson plans, teaching materials, and evaluation instruments in the SMP Kristen Credo Kolongan form the basis for developing teaching materials. The following is an explanation of the stages' results in the development of teaching materials as regulated in TABLE 2. Teaching material specifications are related to science, environment, technology, and communityintegrated scientific competence of the solar system community and the earth's surface structure.

TABLE 2. Teaching material specifications are related to science, environment, technology, and communityintegrated scientific competence of the solar system community and the surface structure of the earth.

\begin{tabular}{ccl}
\hline No & Types of Learning Packages & \multicolumn{1}{c}{ Specification } \\
\hline 1 & Syllabus and Lesson Plan & $\begin{array}{l}\text { Syllabus and Lesson Plan combine CS } 1 \text { (solar system) and CS 2 (earth } \\
\text { surface structure). } \\
\text { Teaching materials are approached with science, environment, } \\
\text { technology, and society to reduce the volcanic ash disaster. }\end{array}$ \\
& $\begin{array}{l}\text { Teaching materials contain material that is equipped with examples that } \\
\text { apply science, environment, technology, society, and evaluation questions } \\
\text { ranging from BC } 1 \text { to BC } 6 \text { to test the cognitive of students at each end of } \\
\text { teaching and learning activities. }\end{array}$ \\
& Learning achievement test questions refer to the cognitive domain C1 \\
& through C4. \\
& The test results of learning outcomes concern the study of earth and space \\
& science "Solar System and Earth Surface structure" with the SETS \\
& approach to mitigation of volcanic ash disasters.
\end{tabular}

The implementation of teaching materials begins with the pretest's performance to determine the students' initial abilities. The learning process is carried out and ends with the implementation of the posttest. Measurement of learning outcomes test is done by comparing the test scores of learning outcomes with the specified minimum completeness criteria and calculating the increase in N-gain pretest-posttest. Analysis of the N-gain test of learning outcomes can be seen in TABLE 3. Analysis of n-gain tests for student learning outcomes on a limited scale trial (simplified).

TABLE 3. Analysis of $n$-gain tests for student learning outcomes on a limited scale trial (simplified).

\begin{tabular}{ccccc}
\hline No & Student Code & Pre test & Post test & N-gain \\
\hline 1. & S-1 & 37 & 93 & 0.8 \\
2. & S-2 & 57 & 97 & 0.9 \\
3. & S-3 & 50 & 93 & 0.9 \\
4. & S-4 & 47 & 97 & 0.9 \\
5. & S-5 & 60 & 100 & 1 \\
6. & S-6 & 33 & 77 & 0.6 \\
7. & S-7 & 40 & 83 & 0.7 \\
8. & S-8 & 43 & 90 & 0.8 \\
9. & S-9 & 43 & 93 & 0.9 \\
10. & S-10 & 50 & 80 & 0.6 \\
& Average value & 46 & 90 & 0.9 \\
\hline
\end{tabular}

Based on the data in TABLE 3. Analysis of n-gain tests for student learning outcomes on a limited scale trial (simplified) shows that the increase in the pretest-posttest reaches the moderate to a high category according to the $\mathrm{N}$-gain criteria (Hake, 1998). After analyzing the T-Test for correlated samples using SPSS, it was found that there were significant differences between the pretest-posttest scores. (1) Output paired samples statistics show the mean for pretest 45.7 and the mean for post-test 90 , while $\mathrm{N}$ for each cell is 11 . The standard deviation for pretest 8.01 , and the standard deviation for post-test 7.7. The mean, standard error for pretest 2.4 and post-test the mean, the standard error is 2 . (2) Output paired samples correlation shows the correlation between the pretest-posttest sample pretestposttest correlation number is seen 0.6 , and the significance value is 0.5 . Decision-making is based on the results obtained probability that is, if the probability $>0.05$, then the null hypothesis is accepted. And if the probability is $<0.05$, then the null hypothesis is rejected. From the analysis of the magnitude of the significance value, 0.5 is greater than 0.05 . This means the null hypothesis, which states a relationship between the pretest-posttest, is accepted. (3) The output paired test sample displays the 
results of a comparative analysis using the t-test. The output shows the mean pretest-posttest is -44.4; the standard deviation is 6.9 , the mean, standard error is 2.1 . The lowest difference was pretest-posttest -49 , while the highest difference was -39.7 . Test results t-test $=-21.5$ with $\mathrm{df}=10$ and significance of 0.00 . Thus, the test's value to to compare $\mathrm{t}\left(\mathrm{t}_{\text {observation }}\right)$ with $\mathrm{t}_{\mathrm{t}}\left(\mathrm{t}_{\text {table }}\right)$, where $\mathrm{df}=10$ obtained figures: 2.3 for a significant level of 5\% and 3.3 for a significant level of $1 \%$. With -21.5 means greater than tt (mathematical sign - (minus) in this case is ignored) at a significant level of $5 \%$ or a significant level of $1 \%(2.3<21.5>3.3)$, which means the hypothesis no rejected.

In wide-scale testing, the measurement results, which are student learning outcomes data, are obtained from the pre-test, post-test, and assignment values from the first meeting to the sixth meeting. Teaching material developed is said to be effective if 30 students get a $\geq 67$ (KKM) grade. Learning outcomes can be seen in TABLE 4. Integrated science learning outcomes that facilitate science, environment, technology, and society for the mitigation of volcanic dust disasters in large-scale trials.

TABLE 4. Integrated science learning outcomes that facilitate science, environment, technology and society for mitigation of volcanic dust disasters in large-scale trials.

\begin{tabular}{lll}
\hline No & Learning Outcomes & Average Rating \\
\cline { 2 - 3 } 1 & Pre-test & Experimentation Class \\
2 & Post-test & 54.5 \\
N-gain & 92 \\
\multicolumn{2}{c}{ Category } & High \\
3 & Assignment assessment \\
4 & Individual assignments from material 1 to & 77 \\
5 & material 6 & 90 \\
6 & Practical work report & 88 \\
\hline
\end{tabular}

TABLE 4. Integrated science learning outcomes that facilitate science, environment, technology, and society to mitigate volcanic dust disasters in large-scale trials show that the highest average pretest score of students received a score of $\leq 80$. In addition to the pretest, the assessment of learning activities was also carried out during the teaching and learning process. Learning evaluation results show that at the first, third, and fourth meetings, the results of the analysis of individual assignments at the end of teaching and learning activities tend to be lower than the fifth and sixth meetings at the meeting. Results of analysis of practical work reports and papers.

The process of making teaching materials related to science, environment, technology, and society. Integrated Science for disaster mitigation of the competence of volcanic dust in the solar system and the earth's surface structure through several stages of research and development. The stages in this study refer to the researcher's initial problem at the time of observation at SMP Kristen Credo Kolongan. From the analysis of findings in the field on the conditions of science learning, teaching materials used by science subject teachers and environmental problems become a basic idea in th is research and development. The findings in the field show that the concept of science is still delivered separately. Teachers' learning media in teaching and learning activities are only focused on textbooks, and the learning methods used are still on the lecture method. Things like this are not following the characteristics of learning science. Science is related to how to systematically find out about nature, so that science is mastering a collection of knowledge in the form of facts, concepts, or principles, and a process of discovery. Science as a process contains an understanding of ways of thinking and acting to deal with or respond to problems in the environment (Haryono 2013). Therefore, it is necessary to develop integrated science teaching materials with science, environment, technology, and society to mitigate volcanic dust disasters.

The integrated learning model used in developing teaching materials in this study is the connection type integrated learning model. This model organizes or integrates a concept, skill, or capability developed and developed in a subject or sub-topic related to the concept, skills, or abilities in another subject or sub-topic in one field of study (Trianto 2007).

The next stage is the validation process of several experts. In this process, the validator assesses the rationalization, practicality, and effectiveness of the teaching materials developed before being trialed. Teaching materials that have been declared valid by experts are then tested on a limited scale. This trial 
aims to determine the effectiveness and practicality of teaching materials before being tested on a wide scale. The effectiveness of teaching materials is seen from learning activities and increasing the pretestposttest value.

In contrast, teaching materials' practicality is seen from students' responses to teaching materials and the teacher's response to teaching materials. Student learning activities on limited scale trials reach active and very active criteria. This is caused by learning activities that are packaged in the form of practical activities using volcano mockups. Student learning outcomes on a limited scale trial following TABLE 3, about the analysis of N-gain which shows that the increase in pretest-posttest students gets moderate to high criteria. Pretest analysis shows that there are significant differences between the pretest and posttest scores. This significant increase and difference state that the teaching material developed is effective for use. Students and teachers in limited scale trials give very good responses to teaching materials, thus showing that teaching materials developed are practically used in teaching and learning activities.

The last stage of developing teaching materials is the large-scale trial phase. At this stage, the effectiveness and practicality of teaching materials are measured with the same indicators when testing a limited scale. Early learning activities, conducted a pretest to determine the initial abilities of students. The results of the pretest, as seen in TABLE 4. Integrated science learning outcomes that facilitate science, environment, technology and society for mitigation of volcanic dust disasters in large-scale trials show that the average pretest score (55) of the experimental class has not yet reached the indicator of the effectiveness of teaching materials in this study, namely 67. This is because students are accustomed to conceptual and one-way learning.

After being given a pretest at the beginning of learning, students are trained to associate concepts with everyday life by teaching materials approaching science, environment, technology, and society. The teaching material involves the active role of students in teaching and learning activities. Indicators of effectiveness in this research development, not only seen from the results of science learning activities on cognitive aspects only. However, to find out the application of teaching materials approaching science, environment, technology, and society integrated science competence of the solar system, and the earth's surface structure is also effectively used in reducing the risk of volcanic dust disaster, volcanic dust disaster simulation activities are carried out to assess students affective aspects.

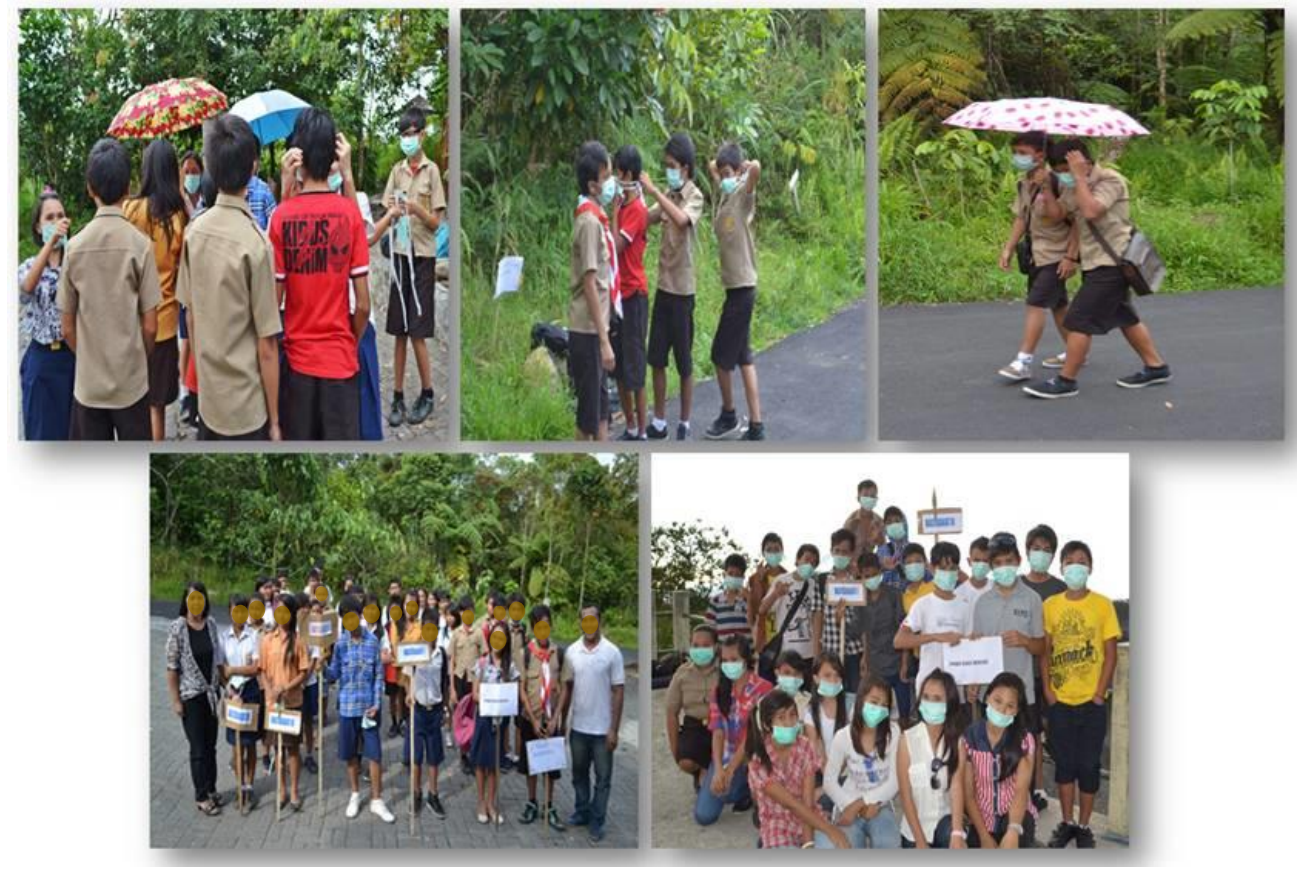

FIGURE 2. Volcanic Dust Disaster Simulation Activity (Salawane 2019)

Teaching materials approaching science, environment, technology, and society integrated science competence of the solar system. The earth's surface structure has several limitations, namely the lack of teaching aids as learning media. It has not produced disaster preparedness schools to develop school preparedness to arouse the awareness of all stakeholders in the field of education both individually and 
collectively in schools and the school environment in terms of readiness against the threat of disaster. Building a culture of alert and safe culture in schools can increase school institutions and individuals' capacity to create a safer place of learning for students, teachers, members of the school community, and the surrounding environment.

\section{CONCLUSION}

Science learning in SMP Kristen Credo Kolongan is still conceptual and one way so that it does not involve students in education, as well as not connecting learning concepts or material with events that occur in daily life. Submission of science is still taught separately, and the unavailability of teaching materials approaching SETS. The teaching material developed in this study has very good criteria seen from students' and teachers' responses so that the teaching materials are integrated with SETS integrated science competencies of the solar system and the earth's surface structure for mitigation of volcanic dust disasters practically used in learning activities.

In this study, teaching materials approached SETS integrated science competence of the solar system. The earth's surface structure was declared effective to reduce the risk of volcanic ash disaster because 30 students were very actively involved in the learning process and reached the specified minimum completeness criteria. There was an increase in the pretest score (54.5) and posttest (92) in the cognitive aspect, whereas in the affective aspect, the students got very good average scores (87.3). These results are in line with previous studies, which state that the development of teaching materials that have been validated by academics, experts, and field practitioners will provide practical, productive and enjoyable results in learning activities (Satinem and Juwati 2018; Wulandari et al. 2018; Demirap 2019).

\section{REFERENCES}

Bernhardsdottir, AE, Musacchio, G, Ferreira, MA \& Falsaperla, S 2016, 'Informal Education for Disaster Risk Reduction', Bulletin of Earth Quake Engineering, vol. 14, pp. 2105-116.

Binadja, A 1999, 'Hakekat dan Tujuan Pendidikan SETS (science, environment, technology, and society) dalam Konteks Kehidupan dan Pendidikan yang ada', Makalah disajikan dalam Seminar Lokakarya Pendidikan SETS, Kerjasama antara SEAMOE RECSAM dan UNNES.

Demirkan, O 2019, 'Pre-service Teachers Views about Digital Teaching Materials', Educational Policy Analysis and Strategic Research, vol. 14, no. 1, pp. 40-60.

Eren, K \& Yagbasan, O 2017, 'Development of Teaching Materials Based on Geographical Information Systems: An Example on Symbolic Sites in Turkey', International Journal of Curriculum and Instruction (IJCI), vol. 9, no. 1, pp. 31-46.

Hake, R 1998, 'Interaktive-Engagement Versus Traditional Methods: A Six-Thousand-Student Survey Of Mechanics Test Data For Introductory Physics Courses', American Association of Physics Teachers, vol. 66, no. 1, pp. 64-74.

Haryono 2013, 'Pembelajaran IPA Yang Menarik dan Mengasyikkan', Kepel Press: Yogyakarta.

Kyne, D, Cisneros, L, Delacruz, J, Lopez, B, Madrid, C, Moran, R, Provencio, A, Ramos, F \& Silva, MF 2020, 'Empirical Evaluation of Disaster Preparedness for Hurricanes in the Rio Grande Valley', Progress in Disaster Science, vol. 5, pp. 1-12.

Maknun, J, Busono, T, \& Surasetjaet, I 2018, 'Envisioning Science Environment Technology and Society’ IOP Conf. Ser.: Mater. Sci. Eng. vol. 306, no. 012064.

Nuvitalia, D, Novita, M, Suciati, S, \& Cholifah, N 2020, 'Teaching-Learning of Phosphor-based LEDs Using Science, Environment, Technology and Society (SETS) Approach', J. Phys.: Conf. Ser., vol. 1464 , no. 012007. 
Olu, O 2018, 'What should the African health workforce know about disasters? Proposed competencies for strengthening public health disaster risk management education in Africa', BMC Med Educ vol. 18 , no. 60 .

Prastowo, A 2012, 'Panduan Kreatif Membuat Bahan Ajar Inovatif', Diva Press, Jogjakarta, p. 301.

Rusilowati, A, Supriyadi, Binadja, A \& Mulyani, SES 2012, 'Mitigasi Bencana Alam berbasis Pembelajaran bervisi Science, Environment, Technology, and Society', Jurnal Pendidikan Fisika Indonesia, vol. 8, pp. 51-60.

Sakurai, A, Sato, T \& Murayama, Y 2020, 'Impact Evaluation of a School-Based Disaster Education Program in a City Affected by the 2011 great East Japan Earthquake and Tsunami Disaster', International Journal of Disaster Risk Reduction, vol. 47, pp. 1-10.

Salawane, C, Supriyadi, Rusilowati, A \& Indriyanti, DR 2019, 'Mitigasi Bencana Debu Vulkanik melalui Pengembangan Perangkat Perkuliahan Berpendekatan SETS Geologi Dasar', Prosiding SNIPS Prodi Fisika FMIPA ITB, pp. 167-72.

Satinem \& Juwati 2018, 'Development of Teaching Materials of Poetry Writing Using Pictures for the Elementary Students', Advances in Language and Literary Studies, vol. 9, no. 3, pp. 1-9.

Supriyadi, Rusilowati, A, Linuwih, S, Binadja, A \& Salawane, C 2019, 'Science Environment Technology and Society Approach Learning to Improve Natural Disaster Mitigation Literacy', Journal of Physics Conference Series, vol. 1387, pp. 1-5.

Szente, J 2016, 'Assisting Children Caught in Disasters: Resources and Suggestions for Practitioners', Early Childhood Educ J, vol. 44, no. 201-207.

Trianto 2007, 'Model Pembelajaran Terpadu Dalam Teori dan Praktek', Prestasi Pustaka: Jakarta.

Tseng, KH, Chang, CC, Lou, SJ, \& Chen, WP 2013, 'Attitudes towards science, technology, engineering and mathematics (STEM) in a project-based learning (PjBL) environment', Int $J$ Technol Des Educ, vol. 23, pp. 87-102.

Widodo, C \& Jasmadi 2008, 'Buku Panduan Menyusun Bahan Ajar', PT Elex Media Komputindo, Jakarta, pp. 40.

Wulandari, T, Suharno \& Triyanto 2018, 'Field Trial Analysis of Teaching Material Civic Education Based on Problem Based Learning (PBL) to Improve Student's Outcome', International Journal of Educational Methodology, vol. 4, no. 4, pp. 259-65. 